\title{
EVALUATION OF DIET OF PEOPLE \\ TRAINING CROSSFIT
}

\author{
Dilyana Zaykova \\ National Sports Academy „Vassil Levski”, Sofia, Bulgaria
}

\begin{abstract}
Introduction: As it is in a number of sports, in CrossFit, nutrition is critical for providing training load and faster recovery processes.

Applied methodology and methods: We surveyed 12 men and 13 women training CrossFit unprofessionally. The average age of the men was 31.5 years, average sports experience of 3.6 years, and performing an average of 3.5 workouts per week. The average age of the women was 28.9 years, average sports experience of 2.7 years, and performing an average of 3.6 workouts per week.

The subjects completed a diet-assessment questionnaire developed by us, which included questions about age, training experience, number of training sessions per week, height and weight and 28 questions about their weekly consumption of basic food products. Basic metabolite rate (BMR) was calculated according to the Harris-Benedict formulas. Daily energy intake (DEI) and daily energy needs (DEN) was calculated om BMR, multiplied by physical activity coefficient dependent on the number of weekly training sessions.

Results: We estimated relative DEN of $34.0 \mathrm{kcal} / \mathrm{kg} B W$ and DEI of $37.4 \mathrm{kcal} / \mathrm{kg}$ of men. The DEN of women was 36.6 $\mathrm{kcal} / \mathrm{kg} B W$ and the DEI was $38.8 \mathrm{kcal} / \mathrm{kg} \mathrm{BW}$. With regard to the intake of proteins, fats and carbohydrates, there are no significant differences between the two groups under study. Intake of fats of animal origin was slightly higher in males than those in the women.

Conclusions: In the study groups, we see a good ration between DEN and DEI and a high relative protein intake and a lower intake of fat, characteristic more about power sports.
\end{abstract}

Key words: CrossFit, nutrition, basic macronutrients, Daily protein intake

\section{INTRODUCTION}

In the last few years, CrossFit has been considered one of the fastest developing sports based on high functional load (Kozub, 2013; Claudino et al, 2018). Like in most sports, proper diet in CrossFit is crucial both for the energy supply of the training load and for the fast recovery (Crossfit inc., 2014; Sousa et al, 2014).

Athletes' daily intake of carbohydrates, proteins, and fats is mainly determined by the intensity of the training load, its content, and the repetitiveness of the weekly cycle. Additional indexes are gender, age, and athletes' qualification (Mcardle et al, 1996; Kreider et al, 2004).

The healthy diet recommendations for people not engaged in sport include about $45-55 \%$ carbohydrates, $15-20 \%$ proteins, and about $20-25 \%$ fat (mostly unsaturated) in their daily energy intake. This also determines the weight values: carbohydrates $(3-5 \mathrm{~g} / \mathrm{kg})$, proteins $(0,8-1,0 \mathrm{~g} / \mathrm{kg})$, and fats $(0,5-1,5 \mathrm{~g} / \mathrm{kg})$ (Kreider et al, 2004).

CrossFit dietitians recommend that the proteins should ensure about $30 \%$ of the daily energy intake (1.5 - $2.2 \mathrm{~g} / \mathrm{kg})$ (Crossfit inc., 2014) in order to maintain muscle growth and recovery after a physical load (Phillips, 2006), (Kim et al, 2018). Their exact quantity is determined by athletes' activity and training experience, as well as by the intensity of the training load (Crossfit inc., 2014).

Carbohydrates should ensure about $40 \%$ of the daily calorie intake (Crossfit inc., 2014). It is recommended that they should mostly be of low to moderate glycemic index (Crossfit inc., 2014; Escobar et al, 2016).

Fats should be about $30 \%$ of the daily energy intake. It is recommended that monounsaturated fatty acids should be prevailing (Crossfit inc., 2014). Thus, one can maintain the energy balance and the inner muscle levels of triglycerides, as well as can ensure the presence of essential fatty acids (Kreider et al, 2014).

The aim of this study was to prove that the actual intake of proteins, carbohydrates and fats is an important factor for the energy supply of athletes practicing CrossFit.

Tasks

1. An inquiry among people (male and female) practicing CrossFit about their diet. 
2. Evaluation of the adequacy of CrossFit men and women's diet.

3. Establishment of the differences between men and women as regards the proportions of the nutrients in their diet.

\section{METHODS}

The research was done among 12 men and 13 women who practice CrossFit professionally at a specialized gym in the city of Sofia. The men's mean age was 31.5 years, their mean training experience was 3.6 years with an average of 3.5 training sessions a week. The women's mean age was 28.9 years, their mean training experience was 2.7 years with an average of 3.6 training sessions a week.

The participants filled in a diet questionnaire, designed by us, which had been used in other surveys with different subjects (Kolimechkov et al, 2016; Petrov, 2017; Zaykova, 2017; Zaykova, Petrov, 2017). The test included questions about the athletes' age, sports experience, number of training sessions per week, stature, weight and 28 questions about the weekly intake of the main nutrients. On the basis of the answers we calculated the daily intake of proteins, carbohydrates, and fats $(\mathrm{kg} / \mathrm{body}$ weight) and their relative share in the energy supply in the daily energy intake (DEI). The relative share of the proteins and fats gained from foods with animal origin was also established.
The basic metabolism was calculated with Harris-Benedict's formulas, and the daily energy needs (DEN) were calculated from the basic metabolism multiplied by a coefficient for physical activity on the basis of the number of training sessions per week (Harris, Benedict, 1999).

As a reference source about the ingredients and energy content of the main food products, included in the questionnaire, we used National Nutrient Database for Standard Reference Release 28, United States Department of Agriculture, Agricultural Research Service.

The results were statistically processed with the help of IBM SPSS 19. In order to evaluate the differences in the mean values we used Student's test for independent samples. The mean values in the texts are presented with the standard deviation (SD), and in the figures - with the standard error (SE).

\section{RESULTS}

As regards DEN and DEP, there were no statistically significant differences between men and women. Figure 1 presents the results obtained for DEN and DEI for all researched individuals. There was a higher DEI among those engaged in sport which could be explained with the high energy expenditure characteristic of CrossFit. There was no statistically significant difference between DEN and DEI.

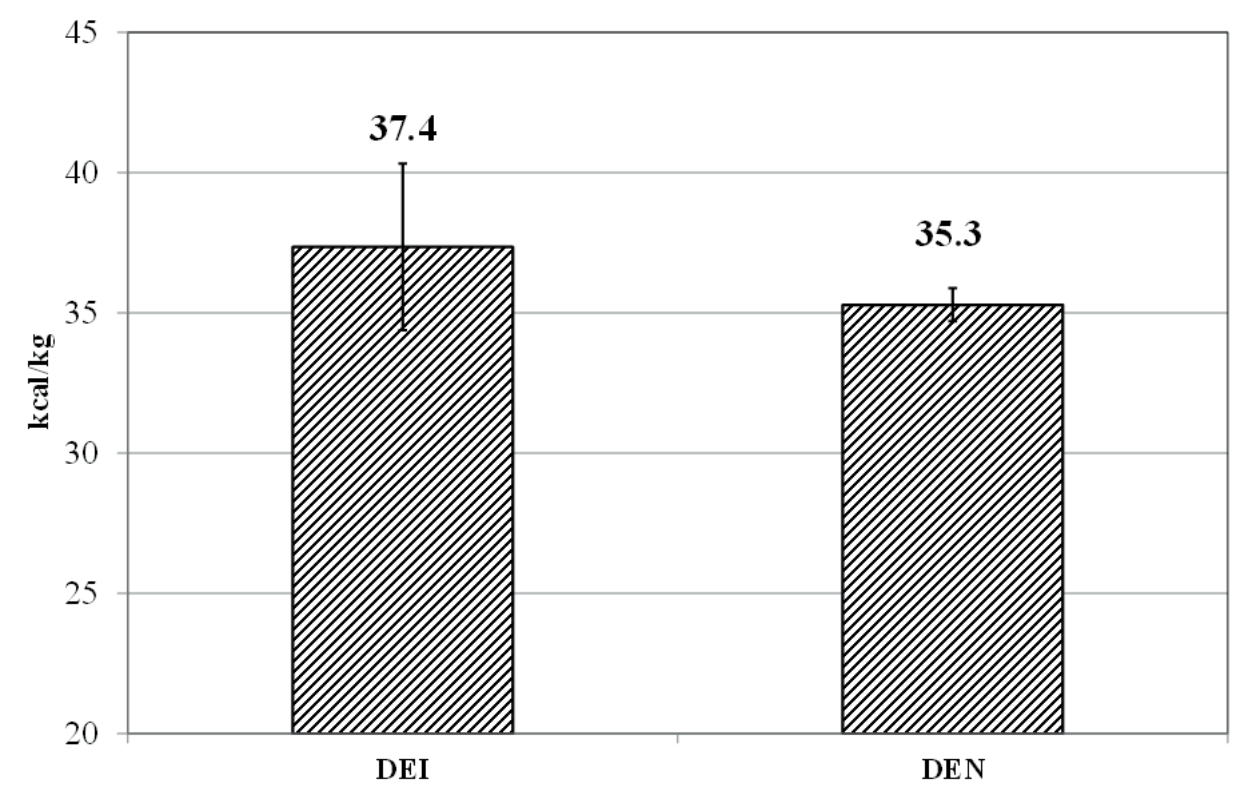

Figure 1. Daily energy needs and daily energy intake

Figure 2 presents the researched individuals' daily tween the men and the women. The protein intake intake of proteins, fats and carbohydrates $(\mathrm{kg} /$ body was on the lower recommended border for those weight). There was no statistically significant differ- who practice CrossFit (Crossfit inc., 2014). ence in the relative share of the nutrient intake be- 


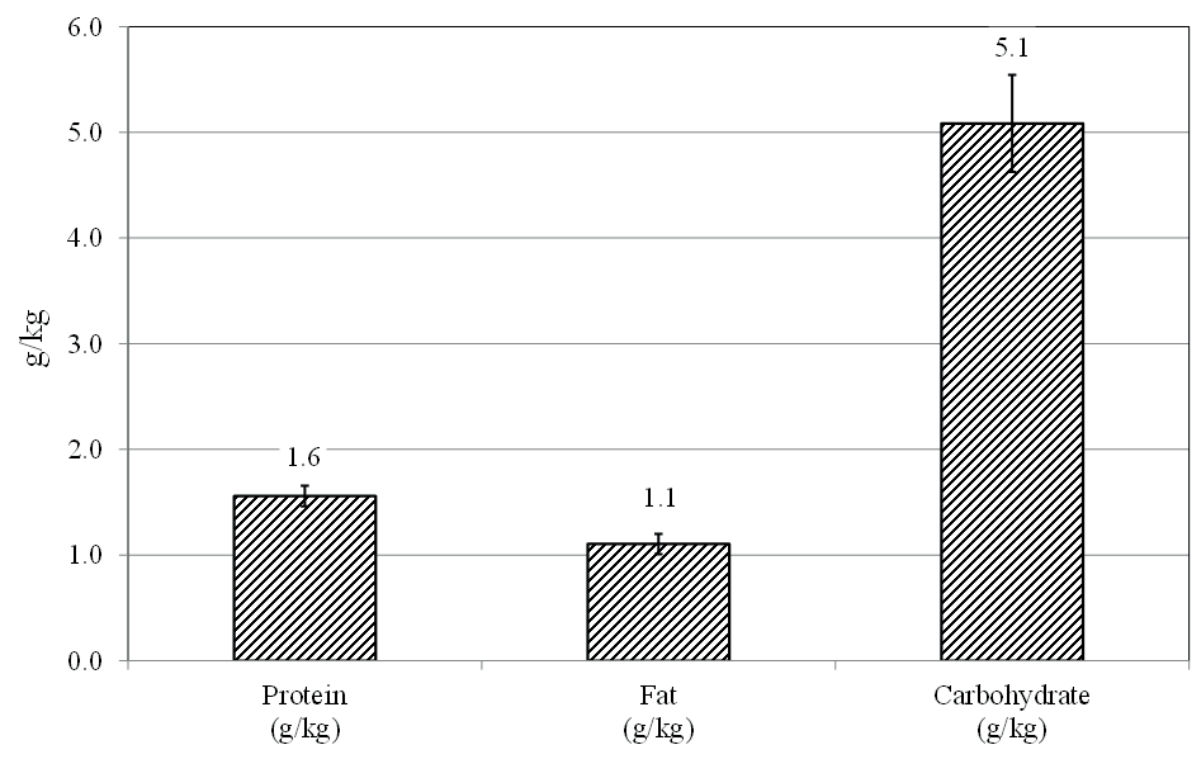

Figure 2. Daily intake of proteins, fats and carbohydrates ( $\mathrm{kg} / \mathrm{body}$ weight)

Figure 3 presents the relative share of the proteins, proteins, there was a significantly lower share (17.7 fats, and carbohydrates in the daily energy intake of \%) than that recommended in CrossFit (30\%). The the subjects. There was a significantly higher intake fats ensured $27.5 \%$ of the energy intake which is of carbohydrates (54.8\%) than the recommended very close to the recommended 30\% (Crossfit inc., $40 \%$ in CrossFit. As regards the energy supplied by 2014 ).

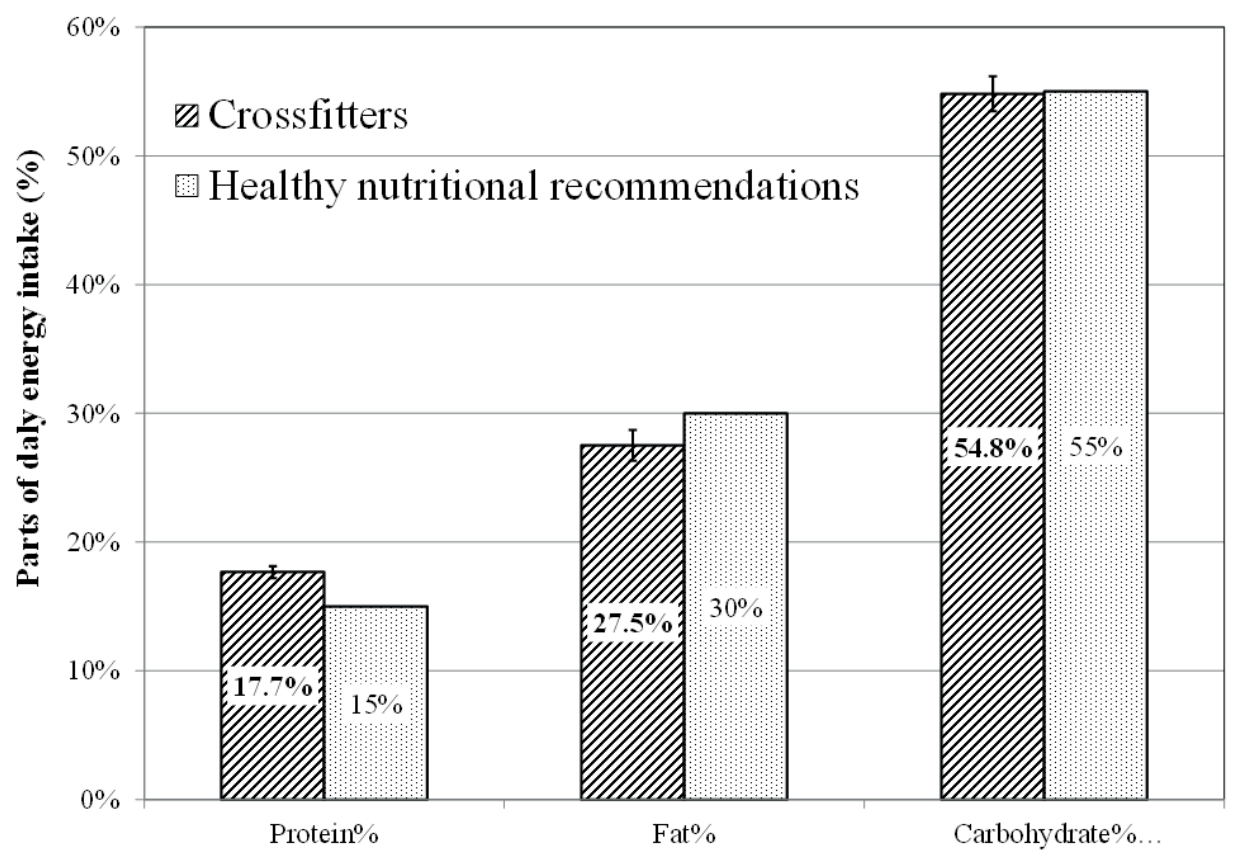

Figure 3. Relative share of the proteins, fats and carbohydrates in the daily energy intake

The proteins gained from foods with animal origin were $53.7 \pm 8.3 \%$. The fats with animal origin were prevailing $68.1 \pm 13.5 \%$. The men reported to have consumed a little greater quantity of fats with animal origin than the women which could be explained with the high intake of meat, fish, eggs, milk and dairy products. There was no statistically significant difference in the intake of protein with animal origin between the researched men and women. 
Figure 4 presents the researched individuals' relative daily intake of proteins. Only the subjects N6 $(2.4 \mathrm{~g} / \mathrm{kg})$ and N20 $(2.6 \mathrm{~g} / \mathrm{kg})$ were over the upper border of the recommended intake of proteins in CrossFit. The subjects N7, N13, and N23 consumed proteins on the level of the upper recommended border. Among 11 of the researched individuals - 5 women and 6 men, there was protein intake lower than the lowest recommended border (Crossfit inc., 2014).

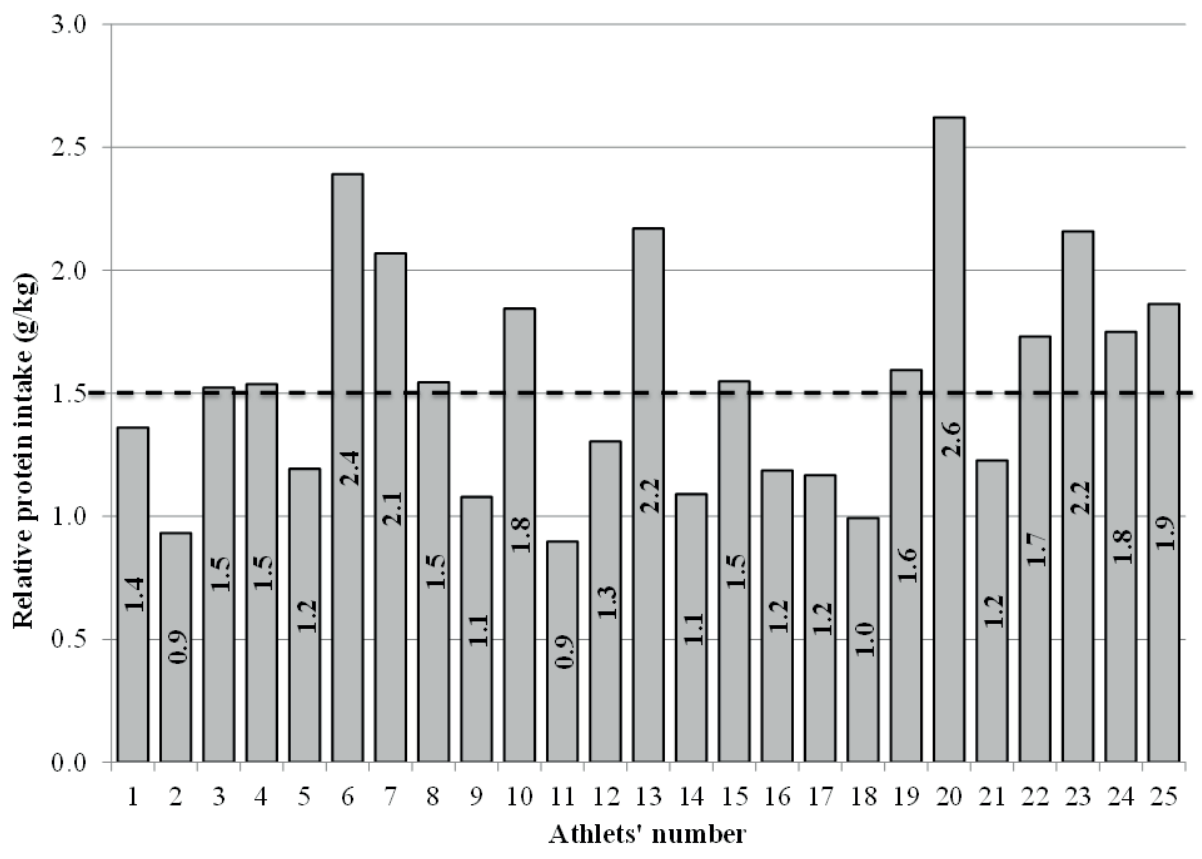

Figure 4. Relative daily intake of proteins. The line shows the lowest recommended border of the relative protein intake $-1.5 \mathrm{~g} / \mathrm{kg}$.

\section{DISCUSSION}

The lack of statistically significant difference between DEN and DEI among the researched individuals shows a satisfactory relevance between the energy needs and the energy intake.

On the one hand, there is an average protein intake on the lower recommended border in CrossFit (1.6 $\mathrm{g} / \mathrm{kg})$. On the other hand, $40 \%$ of the researched individuals consume quantities of protein below this border with an average intake of $1.1 \pm 0.13 \mathrm{~g} / \mathrm{kg}$. These athletes should increase the intake of proteins to over $1.5 \mathrm{~g} / \mathrm{kg}$ which would lead to reaching the relative share of the proteins in the total energy intake of $30 \%$, recommended for those practicing CrossFit.

\section{REFERENCES}

Claudino, J., Gabbett, T., Bourgeois,F., Souza, H., Miranda, R., Mezêncio, B., Soncin,R., Filho, C., Bottaro,M., Hernandez, A., Amadio, A., and Serrão, J. (2018). CrossFit Overview: Systematic Review and Meta-analysis, Sports Med Open

Crossfit inc., (2014). Understanding CrossFit, the Crossfit Trainin Guide, Crossfit.com
Escobar KA, Morales J, Vandusseldorp TA. (2016). The Effect of a Moderately Low and High Carbohydrate Intake on Crossfit Performance, Int J Exerc Sci., 1;9(3), 460-470

Harris, J., Benedict,F. . (1999). A Biometric Study of Basal Metabolism in Man, Washington DC, Carnegie Institute of Washington, 266

Kim IY, Deutz NEP, Wolfe RR. (2018). Update on maximal anabolic response to dietary protein, Clin Nutr., 37(2), 411-418

Kolimechkov, S., Petrov, L., Alexandrova, A., and Atanasov, P. (2016). Nutrition and physical development assessment of pre-school and primary school children practicing artistic gymnastics, African Journal for Physical Activity and Health Sciences, 22 (2:2), 565-577

Kozub FM. (2013). Using the snatch and CrossFit principles to facilitate fitness. JOPERD, 84: 13-16

Kreider, R., Almada, A., et al. (2004). ISSN Exercise and Sport Nutrition Review: Research and Recommendations, Journal of the International Society of Sports $\mathrm{Nu}$ trition, 1(1),1-44

Mcardle, W., Katch, F., and Katch, V. (1996). Exercise physiology-energy, nutrition and human performance, 


\section{Williams \& Wilkins}

Petrov, L. (2017). Otsenka na hraneneto pri jeni, praktikuvashti fitness, silov triboi I vdigane na tejesti, Sport I Nauka, br.3, 2017, pp. 148-160, ISSN 1310-3393

Phillips, S. (2006). Dietary protein for athletes: from requirements to metabolic advantage, Appl Phusiol Nutr Metab, 31(6), 647-54

Sousa M, Teixeira VH, Soares J. (2014). Dietary strategies to recover from exercise-induced muscle damage, Int J Food Sci Nutr., ;65(2), 151-63.

Zaykova, D. (2017). Hranitelen rejim pri sastezateli po borba klasicheski stil ot nacionalno I mejdunarodno nivo, "Predizvikatelstva I perspektivi pred sportnata nauka”, 73-82, NSA PRESS, ISBN 978-954-718-492-3

Zaykova, D., Petrov, L. (2017). Otsenka na hranene- to pri sportovete kulturizam, vdigane na tejesti I silov triboi, "Predizvikatelstva I perspektivi pred sportnata nauka", "Specifika na podgotovkata v razlichni sportni disciplini”, 58-64, IDK NSA PRESS, ISBN 978-954718-457-2

Corresponding author: Dilyana Zaykova National Sports Academy "Vasil Levski", Department "Heavy athletics, boxing, fencing and sport for all" Sofia, 1700, Bulgaria Acad. Stefan Mladenov №21 str. E-mail: dilianazaikova@gmail.com 